\title{
A Feasibility Study of Task-based Teaching of College English Writing in Chinese EFL Context
}

\author{
Linying $\mathrm{Cao}^{1}$ \\ ${ }^{1}$ School of Foreign Languages, Shaanxi Normal University, Xi' an, China \\ Correspondence: Linying Cao, School of Foreign Languages, Shaanxi Normal University, 199 South Chang'an \\ Road, Xi’an City, Shaanxi Province, China. E-mail: linyingcao@snnu.edu.cn
}

Received: July 5, 2012 Accepted: July 24, 2012 Online Published: August 16, 2012

doi:10.5539/elt.v5n10p80 URL: http://dx.doi.org/10.5539/elt.v5n10p80

\begin{abstract}
In this study the author draws on Jane Willis' TBL framework and examines its effects on the improvement of EFL learners' writing competence when such a framework is applied to college writing classrooms in Chinese EFL settings, and thus tentatively explores the feasibility of the task-based approach to the teaching of EFL writing. Results of this study are derived from discussion concerned with qualitative data and quantitative data yielded from a quasi-experiment designed for this research, and reveal that the application of Willis' framework for TBL to Chinese writing classrooms will have some positive influences upon college EFL learners' understanding of a good piece of English writing, greatly help them to solve some problems related to composing, and thereby significantly improve their writing competence. This study attempts to provide the teaching of EFL writing or even the discipline of teaching writing a feasible and effective approach.
\end{abstract}

Keywords: feasibility, writing competence, task-based approach, teaching of EFL writing

\section{Introduction}

It is widely acknowledged that "writing is not only a means of communicating but also a tool of learning a language" (Wolff, 2000). It often helps people to clarify ideas and to create new ones. However EFL learners in Chinese settings score low in English writing task, according to statistics of international language test analysists, such as IELTS, TOFEL. How to improve learners' writing competence is a significant topic for language teachers. This study is undertaken to test an extensively worked-out framework in task-based language pedagogy for its feasibility in improving college EFL learners' writing competence based on a thorough analysis of qualitative and quantitative data yielded from a quasi-experiment in which an experimental class and a control class are designated randomly, in order to tentatively provide the teaching of EFL writing and even the discipline of writing pedagogy and practices another feasible and innovative approach to improving learners' writing competence.

In this study, we refer to Jane Willis' framework for task-based learning as the 'task-based approach', which we tentatively draw on to organize activities in writing classrooms to test whether there is feasibility or not in the improvement of college EFL learners' writing competence under the influence of such a task-based approach, this paper aims to address the following issues:

1. Will 'the task-based approach to the teaching of EFL writing' be a real help for college EFL learners to solve problems encountered in writing classrooms where common writing methods have been adopted?

2. Will 'the task-based approach to the teaching of EFL writing' bring forth significant improvement in college EFL learners' writing competence?

\section{Significance of the Study}

\subsection{Theoretical Significance of the Study}

In the discussion of writing theories and pedagogies, the focus of attention has been on two main approaches, namely 'product-oriented approach' and 'process-oriented approach'. The 'product approach' focuses on "the final product, the coherent, error-free text". The 'process approach', on the other hand, places its emphasis on "the steps involved in drafting and redrafting a piece of work" (Nunan, 2001, p. 272).

However, these two approaches leave some problems unsolved in the teaching of writing because of limitations 
and shortcomings inherent in them. As a consequence of the development of CLT, task-based learning has arrived on language pedagogy scene. As far as TBL is concerned, "both processes and outcomes are taken care of", and furthermore, "there is a compatible and creative relationship between the two" (Nunan, 1989, p. 14). Therefore, if TBL theory is integrated with the teaching of writing, its attention will be naturally focused on both the writing process and end products. However, although much effort has been made to explore the theoretical accounts of task-based language pedagogy (see, for example, Willis, 1996; Skehan, 1998; Bygate, Skehan, and Swain, 2000) and of the teaching of writing ( Horowitz, 1986; Walshe, 1987; Wolff, 2000), the investigation of the task-based teaching of writing, especially task-based teaching of EFL writing, is left rather much untouched. For this reason, through testing whether such a task-based approach is feasible or not in enhancing college EFL learners' writing competence by applying Jane Willis' framework for TBL to college writing classrooms in Chinese settings, this paper is supposed to be considered as a tentative contribution to pedagogical theories pertinent to the task-based teaching of EFL writing.

\subsection{Practical Significance of the Study}

In most college EFL writing classrooms, especially those in Chinese settings, the common teaching model has been adopted through conducting a process which begins with teachers' presentation of prose models to students, then some practices concerning grammatical rules and ends with teachers' written comments on students' compositions. As a result, many teachers and students are merely concerned to see that "the end product is readable, grammatically correct and obeys discourse conventions relating to main points, supporting details and so on" (Nunan, 1989, p. 36), but overlook what they intend to convey in their compositions. Compared to the product approach, the current process approach offers insights into the essence of writing, "focusing as much on the means whereby the complete text was created as the end product itself" (Nunan, 1989, p. 36). The centre of this approach is ideas that are refined, developed and transformed as the writer writes and rewrites. However, this approach neglects grammatical accuracy of compositions to some extent in the teaching of EFL writing. Besides that, mainly due to its relatively long duration in implementation and some difficulties in the control of writing process, the process approach has not completely adopted by the majority of college English teachers yet.

In addition, English writing, as a very important means of international communication, is playing a more and more crucial role in gaining access to modern society. For this reason, a good commanding of English writing becomes an urgent and practical concern for college EFL learners who are in preparation for job-hunting and studying abroad. Thus, college English teachers are entrusted with the responsibility of employing a more practical and efficient approach to help their students improve English writing competence.

As an integration of two main approaches to the teaching of writing, the task-based approach proposed in this study will accentuate the significance of the concern for both grammatical accuracy and fluency in meaning conveyance in the processing of doing tasks in which English is used by the learner "for a communicative purpose (goal) in order to achieve an outcome" (Willis, 1996, p. 23). What' more, this approach will be supposed to greatly facilitate the teaching of EFL writing due to its controllable and flexible procedures.

\section{Theoretical Framework}

\subsection{Introduction to Willis' Framework for TBL}

Around mid-1980s, an approach known as 'task-based learning' (TBL) has slowly emerged to challenge the prevailing orthodoxy of an itemized, form-based methodology as the cornerstone of second and foreign language pedagogy.

The most extensively worked-out framework is that of Jane Willis, who has proposed in her masterpiece $A$ Framework for Task-Based Learning with regard to the definition of 'task' as such: "tasks are always activities where the target language is used by the learner for a communicative purpose (goal) in order to achieve an outcome" (Willis, 1996, p. 23). Task-based classroom activities are envisioned here in terms of a tripartite division into what Willis refers to as the 'pre-task', 'task cycle' and 'language focus' components. (See Table 1).

Table 1. Jane Willis' framework for task-based learning (Adapted from Willis 1996: 53)

\begin{tabular}{ll}
\hline PRE-TASK & Introducing to the task, brainstorming, pre-teaching vocabulary where necessary \\
\hline TASK CYCLE & Task- Planning- Report \\
\hline Language FOCUS & Analysis- Practice \\
\hline
\end{tabular}

In a word, Willis' framework for TBL is a complete guide to the methodology and practice of task-based 
language teaching. It explains and exemplifies each component in a typical task-based lesson, from setting up a task, through the task cycle, leading into language-focused work, encouraging in the learner a concern for both accuracy and fluency.

\subsection{The Task-based Approach to the Teaching of EFL Writing}

Willis doesn't describe how to employ this framework to organize writing classroom activities in detail. According to some clues she have proposed in her masterpiece, the writing practices are deemed to go through the main phrases as such: "this end product will first be introduced orally or through reading in the pre-task phase, then discussed as an integral part of the task stage, drafted collaboratively at the planning stage and finalized for the report stage" (Willis, 1996, p. 62). To put concretely, in the first phase, what need to be done in writing classrooms are mainly some preparatory activities for a specific writing task. The teacher should set a written task, then highlights useful words and phrases, as well as a variety of background knowledge to help students understand task instructions. At the beginning of the second phase 'task cycle', students are firstly required to discuss task orally in pairs or groups to decide how to approach this task while the teacher monitors from a distance. After that, each pair or group will be asked to discuss outline and to write down some notes in the planning stage. Then, the first draft for the task will be asked to finish within one pair or group in required time. Subsequently, drafts will be exchanged with another pair or group asking for some suggestions for improvements. At the end of planning stage, each pair or group will be required to redraft, check, improve their first versions to make final drafts ready for audience. After planning, several pairs or groups of students will be randomly chosen to present their reports to the rest of the class, sharing with other groups what they have found and learnt from their collaboration pertinent to specific features of the written products. In addition, some points worthy of noticing will also be summed up by the teacher. In such a framework for task-based teaching of writing, its core is the task cycle, in which the emphasis is on fluency and spontaneity during the task stage and the planning stage, while the report presentation puts demands on attention to accurate grammatical forms and also contains what need to be finished in what is referred to as 'language focus' in the TBL framework.

As for specific tasks conducted in college EFL writing classrooms, Horowitz summarizes it with a classification of writing tasks employed in college into 7 types: book reports, bibliography, experience reports, reports on theoretical studies, reports on empirical studies, statistical synthesis and reports of experiments (1986, p. 455). In a very real sense, communication tasks used in current college EFL writing classrooms are supposed to be more than what Horowitz has proposed. In other words, all tasks in which learners use appropriate English resources they have for showing writing skills in order to share and compare experiences, to exchange information, to introduce something or someone, to defend themselves and refute others' viewpoints or argue with others, or even to solve some practical or real-life problems, etc. can be considered as what we count in this study.

\subsection{Writing Competence}

What I mean by 'writing performance' in this study is basically underpinned by the four 'competence' defined by Hymes and Canale \& Swain (1980): 'communicative competence'- 'grammatical competence'; 'sociolinguistic competence'; 'discourse competence' and 'strategic competence'. Except that 'strategic competence' needs to be tested during the writing process, the other three 'competences' are supposed to be reflected in the final draft. In view of verifiability, what I tentatively define as 'writing competence' in this research mainly involves those three 'competences', namely 'grammatical competence', 'sociolinguistic competence' and 'discourse competence'.

What are the criteria for measuring EFL learners' writing competence? The best alternative may well be the widely approved writing assessment rubric, namely IELTS profile band descriptors for academic and general training writing module, because IELTS is used for measuring test-takers' English language communicative competence. In IELTS profile band descriptors, writing pieces will be required to be assessed from three aspects including: 'communicative quality', 'arguments, ideas \& evidence' and 'vocabulary \& sentence structure', which almost cover the three 'competences' suggested above, and thereby it will bring forth the analytical marking.

\subsection{Relevant Researches}

Recent years have witnessed an enormous interest in task-based learning and teaching and its increasing application to second/ foreign language instruction (Willis, 1996; Skehan, 1998; Bygate, Skehan, and Swain, 2000). However, the majority of researches pay considerable attention to the relevance between theoretical accounts of task-based learning and language pedagogy.

In contrast, Willis' study into methodology and practice of task-based language teaching and learning by creating a framework can be considered as an innovative attempt to put the underlying principles of TBL into teaching 
practices. As a natural integration of the 'four skills', this supportive methodological framework is supposed to be applied into any classrooms where any language, first, second or foreign is taught and learned. In regard to its specific implementation to a certain course whose focus is on one of the 'four skills', such as writing course, listening course, or reading course, etc, Willis doesn't go into detail in her book.

However, it is worth noting that a few reported studies on task-based approach to EFL language teaching have focused their attention on the organization of classroom activities and effects of Willis' framework for TBL when applied to college EFL writing classrooms (Cai, 2001; Zhu, 2002). So far, however, almost no attempts have been made to examine the correlation between the adoption of such a framework and college EFL learners' writing competence. As such, although the beneficial aspects of Willis' framework for realizing effective language teaching and learning, little has been known about whether the practical implementation of this framework in college EFL writing classrooms especially in Chinese settings, is feasible or not. Therefore, my research can be probably considered as the first attempt to investigate this issue.

\section{Methodology}

\subsection{Participants}

Two classes of graduate students taking English writing course in their first year of study in Shaanxi Normal University were designated randomly as an experimental class and a control class in this research, each of which had 40 regular students. The subjects were randomly assigned to those two classes based on their general performance in the placement test administered before they began their graduate study. Their ages ranged from 21 to 35 and those who were at the age of 22 or 23 accounted for 54 percent of the total. Owing to some conditional restrictions, we had to take Chinese college EFL learners as subjects of this research with the expectation that what they performed in this experiment would reflect to the largest extent the most essential features of the whole population of college EFL learners in terms of writing competence.

\subsection{Variables}

In this two-group experiment, we attempt to test whether or not 'the task-based approach to the teaching of EFL writing', or more specifically, the application of Willis' framework for task-based learning to Chinese EFL writing classrooms has a positive effect on college EFL learners' writing competence. "In an experiment, we compare the performance of subjects in the different treatment conditions and attempt to attribute differences in behavior to the feature (or features) that is (or are) different - i.e., that vary - across the conditions" (Keppel, 1982, p. 6). As different treatments, the task-based approach to the teaching of EFL writing and the common teaching method are characterized by "a particular combination of potentially critical features". Because "the independent variable is usually defined by the nature of the critical differences systematically varied among the treatment conditions" (Keppel, 1982, p. 6), I thereby refer to different teaching methods of EFL writing as independent variable, and college EFL learners' writing competence, which can be reflected through their writing test results in a direct way, as dependent variable. For this reason, the experiment to be conducted in this study is supposed to be regarded as a single-factor experiment.

In fact, in addition to teaching methods which directly influences learners' writing competence, other factors are very likely to have an effect on how they behave in their writing to some extent, for instance: linguistic background, educational attainment, personality, personal interest, etc. However, in this single-factor experiment, it required us to have strict control over all factors other than teaching methods to make those factors didn't work in explaining cause-effect correlation between the independent variable and the dependent variable. In this experiment, the random assignment of subjects to different treatment conditions was adopted to guarantee that two groups are at the same level when we began to conduct the experiment. What's more, we treated the subjects of two groups in different conditions exactly alike in every aspect except for the necessary variation in teaching methods of EFL writing through controlling other features or factors, though not absolute, to keep sufficiently constant in the whole process of the experiment.

\subsection{Procedures}

The experiment was conducted from October 29 to December 3, 2011. In the six-week experiment, each student in the experimental class and the control class had composed six writing pieces, two of which were written without any teacher's control (one was taken as the pretest and the other the posttest). However, as far as the other four compositions were concerned, the approaches to teaching composition varied from the experimental class to the control one. Or more specifically, the task-based approach to the teaching of EFL writing was adopted in the experimental class, while what was adopted in the writing instruction for students in the control class was still the common teaching method. Except for this difference, all other conditions or factors including 
age, linguistic background, educational attainments, topics of writing pieces, etc. would remain basically the same in these two classes.

\section{Data Collection and Processing}

\subsection{Qualitative Data}

In this research, qualitative data were yielded from two questionnaires, namely pre-experiment questionnaire and post-experiment questionnaire. To go further, by calculating percentages of subjects who had chosen any choice for a certain question, qualitative data were obtained and then analyzed descriptively in order to determine what trends the data suggested about some issues that this research attempted to explore.

\subsection{Quantitative Data}

This research regarded subjects' scores of three tests, including the placement test, the pretest and the posttest, as quantitative raw data. Two experienced raters, who were professors from Foreign Languages Department of Shaanxi Normal University, would mark subjects' writing pieces based on the combination of two scoring methods and gave them scores. Then, Statistical Package for the Social Science (SPSS 13.0) was exploited to process the raw data, and thus the means and standard deviations of both the control class and the experimental class in those three tests were obtained. On the basis of processed data, the t-test would help to decide whether the difference demonstrated between two classes arose from different approaches to the teaching of EFL writing or from other occasional factors.

\subsection{Scoring Methods for Quantitative Data Collection}

The author employed holistic (global or impressionistic) marking and analytic (profile) marking in this experiment. The former is used when the raters are asked to give a judgment on a candidate's performance as a whole, while the latter is used when the raters are required to judge several components of a performance separately. In this research, the holistic marking was based on the writing assessment rubric of Collge English Proficiency Test (CET 4) testing syllabus and the analytic marking was in accordance with IELTS Profile Band Descriptors for Academic and General Training Writing Module. Since the score a rater gave to a student was a combination of the holistic result and the analytic one and furthermore the full score of each marking was 15 points, a writing piece for both the pretest and the posttest was marked by a rater two times (one was based on the holistic marking and the other the analytic one) and subsequently the rater gave the average of two scores as the final score. In order to enhance the reliability in scoring process, two raters were required to score a writing piece singly. Accordingly, the final result of the writing pretest or posttest for every student was the average of scores given by two raters. However, it should be noted that we needed to take the issue whether there was a correlation between scores given by rater A and that given by rater B into consideration before processing those raw data.

Therefore, we attempted to conduct an inter-rater reliability analysis by computing their correlation coefficient $r$ (Pearson Correlation Coefficient) in the scoring process by means of SPSS 10.0, and then the value of $r$ was put in a function to obtain $\mathrm{r}_{\mathrm{AB}}\left(\mathrm{r}_{\mathrm{AB}}=2 \mathrm{r} /(1+\mathrm{r})\right.$ ), the value of correlation reliability of two raters' rating of the pretest or the posttest. If the value of $r_{A B}$ was great enough, scores given by rater $A$ were correlative to those given by rater $B$; if the value of $r_{A B}$ was not great enough, there was no correlation between scores given by two raters.

\section{Qualitative and Quantitative Results}

\subsection{Qualitative Results}

Questionnaires were designed to observe qualitatively changes related to college EFL learners' writing competence occurring in the task-based writing classrooms, or more specifically, to observe whether the application of such a framework for task-based learning to Chinese college EFL writing classrooms is a real help for learners to solve their problems encountered in writing classrooms where common writing methods have been adopted.

\subsection{Quantitative Results}

In order to explore whether Jane Willis' framework for task-based learning will bring forth significant improvement in college EFL learners' writing competence, the analysis based on quantitative data is supposed to provide readers with more direct and convincing evidence. According to writing specialists, when it comes to testing at the college level, nothing gets at writing better than writing itself. Consequently, most college students' writing competence is measured in accordance with their scores of relevant tests, EFL learners are without exception. 


\subsubsection{Placement Test and Pretest}

Before those graduate students began their study in Shaanxi Normal University, they took a placement test, which contained several parts as follows: listening comprehension, vocabulary \& grammar, cloze, reading comprehension and writing.

The mean scores and standard deviations (S.D.) of this test were compared between the experimental class and the control class as presented in Table 2, which clearly shows us approximate equivalence of mean scores of two groups in the hundred-mark system, indicating that subjects in both the experimental class and the control class were basically at the same English level.

Table 2. Results of placement test

\begin{tabular}{llllll}
\hline & $\mathrm{N}$ & Highest mark & Lowest mark & Mean & S.D \\
\hline Experimental class & 40 & 85 & 64 & 75.28 & 5.60 \\
\hline Control class & 40 & 85 & 62 & 73.26 & 6.62 \\
\hline
\end{tabular}

Before the experiment, a pretest of writing was conducted in two classes as required. As mentioned above, two raters scored 74 students' writing pieces singly in accordance with two scoring rubrics. For this reason, inter-rater correlation reliability of the pretest should be examined. Based on the value of Pearson Correlation Coefficient $r$ shown in Table 3 and a pertinent function, we got an acceptable $r_{A B}$ value $\left(r_{A B}=0.94\right)$, which directly indicates that there is a strong correlation between scores rated by rater A and that rated by rater $\mathrm{B}$ in the pretest.

Table 3. Correlation of two raters' rating of the pretest

\begin{tabular}{llcc}
\hline & & Rater A (for pretest) & Rater B (for pretest) \\
\hline Rater A (for pretest) & Pearson Correlation & 1.000 & $.890^{* *}$ \\
& Sig.(2-tailed) &. & .000 \\
& $\mathrm{~N}$ & 74 & 74 \\
\hline Rater B (for pretest) & Pearson Correlation & $.890^{* *}$ & 1.000 \\
& Sig.(2-tailed) & .000 & 74 \\
& $\mathrm{~N}$ & 74 &. \\
\hline
\end{tabular}

**. Correlation is significant at the 0.01 level (2-tailed)

After the verification of the existence of correlation of two rater's rating, we further found out that the distribution of scores of two groups were close to the standard normal distribution. Thus, because of the comparison of means of pretest between the experimental class and the control class, independent samples t-test was adopted to testify whether any significant difference existed or not.

Table 4. Independent samples t-test results of the pretest

\begin{tabular}{lllllll}
\hline & $\mathrm{N}$ & Mean & S.D. & $t$ & $d f$ & Sig. (2-tailed) \\
\hline Experimental class & 40 & 8.3127 & 1.2512 & 0.945 & 70 & 0.314 \\
\cline { 1 - 3 } Control class & 40 & 8.6126 & 1.3029 & & & \\
\hline
\end{tabular}

As Table 4 demonstrates, there is no significant difference between the mean score of the experimental group and that of the control group $(\mathrm{t}=0.945, \mathrm{P}(\mathrm{Sig})=.0.314>0.05)$. From those descriptive evidences displayed above, we are assured of the fact that graduate students in the control class and the experimental class were not only of almost the same English level but also of the same level of English writing competence before the experiment.

\subsubsection{Posttest}

At the end of the experiment, a posttest of writing was given to the experimental class and the control one, and the information related to the writing task for the posttest is described above. Moreover, in order to minimize the influences of threats to internal validity on raw data as much as possible, the difficulty of the writing task for the 
posttest remained the same with that of the pretest's writing task to a greatest extent to ensure the validity of this experiment.

Although the posttest adopted the same scoring methods as the pretest, and furthermore subjects' compositions in the posttest were still assessed by the same raters as the pretest, its correlation of two raters' rating still needed to be checked to ensure the correlation reliability in the scoring process of the posttest.

Table 5. Correlation of two raters' rating of the protest

\begin{tabular}{llll}
\hline & & Rater A (for protest) & Rater B (for protest) \\
\hline Rater A (for protest) & Pearson Correlation & 1.000 & $694^{* *}$ \\
& Sig.(2-tailed) &. & .000 \\
& $\mathrm{~N}$ & 74 & 74 \\
\hline Rater B (for protest) & Pearson Correlation & $.694^{* *}$ & 1.000 \\
& Sig.(2-tailed) & .000 &. \\
& $\mathrm{~N}$ & 74 & 74 \\
\hline
\end{tabular}

**. Correlation is significant at the 0.01 level (2-tailed)

Table 5 provides detailed information, on the basis of which an acceptable $r_{A B}$ value $\left(r_{A B}=0.82\right)$ is obtained. Because it is large enough, we are sure of a strong correlation between scores given by rater A and that given by rater B.In order to provide the most convincing evidence for this feasibility study of task-based approach to improving college EFL learners' writing competence, the statistical analysis of the posttest is supposed to be done in a comprehensive way. On the one hand, within one group, either the experimental one or the control one, a paired samples t-test will be employed to examine whether the mean score of a certain group in the posttest is of significant difference or not in comparison to its mean score of the pretest. On the other hand, as far as the posttest is concerned, the mean score of the experimental class will be compared with that of the control class by employing an independent samples t-test. The following three tables are presented as the result of such an all-sided comparison.

Table 6. Paired samples t-test of the control class

\begin{tabular}{llllllll}
\hline Protest & $\mathrm{N}$ & Mean & S.D. & $\begin{array}{l}\text { Mean } \\
\text { Difference }\end{array}$ & $t$ & $d f$ & Sig. (2-tailed) \\
\cline { 1 - 4 } Pretest & 40 & 8.6127 & 1.3512 & 0.1420 & 0.918 & 35 & 0.356 \\
\hline Posttest & 40 & 8.4126 & 1.0192 & & & & \\
\hline
\end{tabular}

The results presented in Table 6 reveal that there is no significant shift in the comparison between the posttest mean score of the control class and its pretest mean score $(t=0.918, P=0.356>0.05)$. As for its reason, it is no more than that there is no change in all factors that more or less affect subjects' writing competence during the experiment in comparison to those occurring prior to the experiment. Consequently, the average EFL writing performance of subjects in the control class remains constant throughout the whole process of this experiment.

Table 7. Paired samples t-test of the exprimental class

\begin{tabular}{|c|c|c|c|c|c|c|c|}
\hline & $\mathrm{N}$ & Mean & S.D. & $\begin{array}{l}\text { Mean } \\
\text { Difference }\end{array}$ & $t$ & $d f$ & Sig. (2-tailed) \\
\hline Pretest & 40 & 8.3327 & 1.2512 & -1.2876 & $-5,231$ & 36 & 0.000 \\
\hline Posttest & 40 & 9.6126 & 1.2192 & & & & \\
\hline
\end{tabular}

From Table 7, it can be found out clearly that the posttest mean score of the experimental class is higher than its pretest mean score by about 1.3 points.

Table. 8. Independent samples t-test results of the posttest

\begin{tabular}{lllllll}
\hline & $\mathrm{N}$ & Mean & S.D. & $t$ & $d f$ & Sig. (2-tailed) \\
\cline { 1 - 4 } Experimental & 40 & 9.3327 & 1.2512 & -4.231 & 72 & 0.000 \\
\cline { 1 - 3 } Control & 40 & 8.6126 & 1.0192 & & & \\
\hline
\end{tabular}


Similarly, Table 8 indicates that the posttest mean score of the experiment is also higher than that of the control class by about 1.1 points. What's more, in regard to either the former or the latter, such a difference is very significant in terms of statistics for the reason that the value of $\mathrm{P}$ (Sig.) is constantly less than $\alpha(\alpha=0.05)$. Thus, in view of the fact that students' writing test results generally directly reflect their overall writing competence, it can be deemed that such a significant increase in mean scores of writing tests can be considered as the most convincing evidence of a significant improvement of subjects' writing competence.

\section{Discussion}

On the basis of a thorough analysis of qualitative and quantitative results obtained from the quasi-experiment designed for this research, it can be firmly believed that enough convincing evidence are supposed to be provided to address the research questions in a comprehensive way.

\subsection{On the First Research Question}

In order to investigate whether the task-based approach to English writing pedagogy helps effectively college EFL learners with their unsolved difficulties encountered in former English writing practices, we need firstly to have a clear idea of what their greatest difficulties are. According to the result of the pre-experiment questionnaire, more than half of subjects regarded 'content or idea' as their greatest difficulty, and the proportion of subjects who chose 'rhetorical organization' as their biggest problems reached one fourth. In contrast, 'vocabulary and sentence structure' and 'fluency' turned out to be the unweighted items. However, the reasons why such a result was obtained are easy to be found. On the one hand, having studied English systematically for almost 10 years, those graduate students are supposed to have built a comparatively solid foundation for sentence structure and other grammatical items. Moreover, the vocabulary they have mastered is also rather high to reach a particular point or level.

According to the survey, nearly three fourths of subjects claimed that they had had their former English writing courses under teachers' instruction of 'guided writing', which was characteristic of the attachment of importance to correctness of language usage and form of end product. In such writing classrooms, learners "view composing as more mechanical and formulaic" and thus they are so inhibited that "they cannot get beyond the surface in order to anticipate the needs and expectations of their readers" (Nunan, 1989, p. 35). As a result, they always failed in conveying their intended meaning successfully to readers. Similarly, as for 'rhetorical organization' that is purely productive composing skill, most students also lack relevant training in their former English writing classrooms in which their individual logic and arrangement may have disappeared to some extent because of the existence of the form of 'guided writing'. Thus, the majority of subjects have left those two aspects unsolved until now, especially 'content or idea'. However, through six-week EFL writing training on the basis of Jane Willis' framework for task-based learning, we succeeded in getting positive responses from all of subjects, among whom there were about one third of students subscribing to the view that such a writing course indeed help them with former difficulties 'to a great extent' and other subjects agreed that the task-based EFL writing course has provided them with a good access to addressing their troubles 'to some extent'. To go into detail, with regards every component of writing competence, the tendency to a certain extent of improvement in EFL writing competence varies from one subject to another. As the results illustrate, there is a remarkable coincidence that the majority of subjects believe that they have made much progress with how to deal with issues concerned with such aspects as 'content or idea', 'rhetorical organization', 'sentence structure and vocabulary', 'fluency' and 'logic'. In particular, after they have had such a task-based writing course, subjects who confirmed that they have made giant strides in expressing their ideas with written language accounted for as high as 63.3 percent of the total. As for such a result, we don't consider it to be unexpected at all. As stated early, what we mean by task-based approach to the teaching of EFL writing is really characteristic of the application of Jane Willis' framework for task-based learning to EFL writing classrooms. Thus, college EFL learners who received writing training in such courses on the basis of TBL would pay much more attention to conveyance of intended meaning or idea than before and try to communicate with readers effectively in order to have a clear idea of their needs and expectation with the development of 'task cycle', the design of which offers learners the chance to use whatever language they already know in order to carry the meanings they wish to express.

What' more, as final drafts are ready for audience, namely the rest of the class, a cohesive and coherent writing piece will be demanded. Hence logical organization and fluency are what students count here. Although 'rhetorical organization', 'logic' and 'fluency' are the least touched items in peers' evaluation, learners have to resort to other means to achieve them as much as possible, and consequently there is also an improvement in their abilities to address such problems. On the other hand, in later stage - 'language focus' - accuracy of the language does matter, and thus learners are ready to focus on the specific forms that carry their intended meaning 
depending on teachers' analysis and suggestions. More than that, peers will suggest improvements concerning sentence structure and vocabulary in a pair or between pairs. As stated above, because most students have certain knowledge of this aspect, their suggestions and teachers' are supposed to be complementary and have a strong pertinence and consequently there are 83.4 percent of subjects who have made good progress with correct use of 'sentence structure and vocabulary'.

\subsection{On the Second Research Question}

Will 'the task-based approach to the teaching of EFL writing' bring forth significant improvement in college EFL learners' writing competence? Based on the systemic analysis of quantitative results, the answer to this question is undoubtedly affirmative.

As discussed above, quantitative results of this research, which are regarded as the strongest and the most direct evidence of college EFL learners' writing competence improvement. Drawing on SPSS analysis of test results, we have found out the following evidences leading to the conclusion that college EFL learners' writing competence can be really enhanced in this experiment. For one thing, before the experiment was conducted, subjects in the experimental class and the control one were fundamentally at the same level in terms of comprehensive skills reflected in the placement test. Secondly, on the basis of statistical verification of a strong correlation between scores rated by rater A and those by rater B, we made an all-sided comparison of results of two groups in the pretest and the posttest: between two groups, there is a significant difference between the posttest mean score of the experimental class and that of the control class, or more specifically, the posttest mean score of the experimental class is significantly higher than that of the control class, while subjects in two groups were basically at the same level of English writing competence before the experiment was conducted; within one group, there is also a significant increase of the posttest mean score of the experimental class in comparison to its pretest mean score, whereas there is no significant difference in regards to mean scores of the control class between the pretest and the posttest.

In addition, according to the statistical analysis based on an authoritative Database (This database is developed by Prof. Yang Yonglin, who has authorized me to employ it to process data.) for writing analysis, most subjects of the experimental class in the writing posttest had a much better performance than those of the control one in the posttest, and their writing performance in this test was also better than theirs in the pretest. To put concretely, the total number of words used by an average subject of the experimental class in his or her writing piece for the posttest is 249 , which contains 198 words falling into 'the most frequently-used 1000 words', 12 words belonging to 'the second most frequently-used 1000 words', 13 academic words and 24 words that can be put into other categories. However, as for the above items related to the control class in the posttest and the experimental class in the pretest, the results are 147(115-6-9-16) [(115-6-9-16) means that 147 words contains 115 belonging to 'the most frequently-used 1000 words', 6 words that fall into 'the second most frequently-used 1000 words', 9 academic words and 16 words that can be put into other categories.] and 144 (119-13-0-10) respectively. Despite the average total number of words of the experimental class in the posttest is the largest of the three objects need to be compared, its average total number of different words is the largest (142) and thus its recurrence rate of words is the smallest (0.57). Besides that, in terms of 'the average length of words' and 'the average length of sentences', the performance of subjects of the experimental class in the posttest can be considered to be better than their performance in the pretest and what subjects of the control class have performed in the posttest (the specific results: 'the average length of words' 4.59-4.47-4.55; 'the average length of sentences 15.53-13.44-13.93). Accordingly, it can be inferred from the above figures that most students in the experimental group were able to exploit more diversified words, more 'big' words, and more sentences with complicated structures to compose their writing pieces in the posttest than they did in the pretest, or the peers in the control group did in the posttest. What's more, the inference is sure to strengthen the credibility of the conclusion derived from the SPSS analysis of scores rated by two raters. Owing to a strict control of all factors which more or less have an effect on the change of subjects' writing test results other than pedagogical treatments (i.e. the task-based approach to the teaching of EFL writing vs. common teaching methods of EFL writing), it can be affirmed that writing competence transformation of subjects in the experiment class is the direct result of the intervention of pedagogical treatment different from that applied to the control class. In other words, as far as subjects in the experimental class are concerned, their significant improvement in English writing competence is supposed to be brought forth by the adoption of the task-based approach to the teaching of EFL writing, or more specifically, the application of Jane Willis framework for task-base learning to EFL writing classrooms.

\section{Conclusion}

As a complete guide to the methodology and practice of task-based language teaching, Jane Willis' framework 
for task-based learning is assumed to be a tentative combination of 'the process approach' and 'the product process' when it is applied to college EFL writing classrooms and consequently the findings of this study indicate that such a task-based approach can be considered to be really feasible for college EFL learners to improve their English writing competence. The major findings will be concluded as follows:

1. The task-based approach characteristic of Jane Willis' framework fortask-based learning genuinely brings forth a major shift from teacher-centered writing instructions to learner-centered writing instructions, and thus excites college EFL learners' interests to a large extent to participate in a series of communicative activities in order to achieve a written outcome.

2. Under instructions of Willis' framework for TBL, the whole writing process undergoes at the level of meaning that learners wish to convey in their writing pieces, and thereby college EFL learners gradually build an understanding of viewing English composing from a more global perspective not merely concentrating on specific language forms.

3. Due to the fact that Willis' framework for TBL gives college EFL learners experience of spontaneous interaction with peers, learners are able to find out the needs and expectations of their readers and gain some valuable suggestions for further improvement in terms of content, rhetorical organization and language forms, and thus make good progress in solving problems encountered in their former writing practices.

4. The application of Willis' framework for TBL to college EFL writing classrooms positively brings forth significant improvement of learners' English writing competence, which involves the increase of average sentence length, the increase of average number of big words or academic words, and the increase of salience of lexical diversity (or the decrease of average lexical recurrence rate).

\section{Limitations and Suggestions}

Although the findings of this study are largely positive, several limitations should be noted here. First, the subjects of this research are 74 Chinese EFL graduates with various majors other than English in Shaanxi Normal University, and consequently, the findings are possibly limited to EFL learners with a profile similar to those participating in this quasi-experiment. Thus, in interpreting the results yielded from this research, we should bear in mind that its sampling that is not completely random and the subjects' exclusion of EFL undergraduates may have affected the accurate reflection of whole population of college EFL learners to some degree. Secondly, it must be acknowledged that the administration of questionnaires written in English to a group of Chinese college EFL learners is more or less problematic. It is very likely that a few subjects may misunderstand certain questions or interpret them in ways other than what we intends. For this reason, the information yielded from qualitative results might not give us a real reflection of what they have considered about some issues concerned with EFL writing competence. Thirdly, fundamentally speaking, this study focuses its attention upon the investigation of whether such a task-based approach is feasible or not in college EFL writing classrooms, lacking the fullest consideration for theoretical exploration into Willis' Framework for task-based learning as an EFL writing pedagogy. Besides that, with regards the issue concerning task design, this paper doesn't pay enough attention and consequently such aspects as task complexity, task difficulty and task production leave unmentioned.

The findings of this study bear significant implications for organizing writing activities under Jane Willis' framework for task-based learning in college EFL classrooms for enhancing learners' writing competence.

First of all, different from the common PPP model, the center of such writing classrooms has been transformed from teachers to learners, or more specifically, student writers, who take full advantage of interaction introduced by the framework to discuss content, to ask for suggestions, to solve problems, and to compose final drafts. Accordingly, in such an EFL writing classroom where activities are organized in accordance with Willis' framework for TBL, it is expected that teachers and learners will locate themselves accurately and conveniently.

Secondly, integrating the 'product approach' into the 'process approach', the teaching of writing characteristic of Willis' framework for TBL stimulates interaction and encourages collaborative writing among learners mainly at the level of meaning or content in 'task cycle', while at the end of the framework the focus turns to language form.

Thirdly, although various textbooks or teaching materials have been published on the basis of task-based learning, almost none of textbooks for teaching composing have really designed in accordance with Willis' framework for TBL yet. However, the successful verification of existence of feasibility in the application of Willis' framework for task-based learning to college EFL writing classrooms have outlined how such a flexible but coherent framework is employed to practically organize EFL writing classroom activities, and therefore some 
valuable insights will possibly be contributed to how to design the textbooks or teaching materials pertinent to the teaching of EFL writing and even to the whole writing pedagogy.

In conclusion, the tentative application of Willis' framework for task-based learning to college EFL writing classrooms in Chinese settings fundamentally authenticates that such a task-based approach to the teaching of EFL writing is feasible in improving college EFL learners' writing competence and thereby we are justified in believing such a task-based approach will probably be one of the guideline to the methodology and practice of the teaching of EFL writing or even the discipline of writing pedagogy. However, limitations of this study, which have been mentioned above, demonstrate that some issues related to this subject need further improvement, perfection and in-depth exploration. According to me, future investigation will be supposed to take into account specific linguistic features of college EFL learners' compositions written under instructions of such a task-based approach. What's more, considerations of individual learner differences, including motivation, attitude, gender, learning style and how such variables may affect the application of TBL to the teaching of EFL writing can also lead to future relevant researches that will add substantially to the literature on task-based writing pedagogy or even on task-based language teaching and learning.

\section{References}

Bygate, M. P. Skehan, \& M. Swain. (eds.). (2000). Researching Pedagogical Tasks: Second Language Learning, Teaching and Testing. Essex: Longman.

Cai, L. Z. (2001). Application of task-based learning in English writing. Foreign Language Circle Journal, 4, $18-22$.

Cook, V. (2000). Second Language Learning and Language Teaching. Beijing: Foreign Language Teaching and Research Press.

Ellis, R. (2000). Task-based research and language pedagogy. Language Teaching Research, 4(3), 193-220.

Foster, P., \& P. Skehan. (1996). The influence of planning and task type on second language Performance. Studies in Second Language Acquisition, 18(3), 299-325. http://dx.doi.org/10.1017/S0272263100015047

Horowitz, D. (1986a). Process not product: less than meets the eyes. TESOL Quarterly, 20(1), 141-144. http://dx.doi.org/10.2307/3586397

Horowitz, D. (1986b). What professors actually required: academic tasks for the EFL classrooms. TESOL Quarterly, 20(1), 445-462. http://dx.doi.org/10.2307/3586294

Hymes, D. H. (1979). On communicative competence. In Brumfit, C. J., \& K. Johnson (eds.), The Communicative Approach to Language Teaching. Oxford: Oxford University Press.

Keppel, G. (1982). Design and Analysis: A Researcher's Handbook. New Jersey: Prentice-Hall, Inc.

Long, M. (1993). Three approaches to task-based syllabus design. TESOL Quarterly, 26, 27-56.

Nunan, D. (1989). Designing Tasks for the Communicative Classroom. Cambridge: Cambridge University Press.

Nunan, D. (2001). Second Language Teaching and Learning. Beijing: Foreign Language Teaching and Research Press.

Skehan, P. (1996). A framework for the implementation of task-based instruction. Applied Linguistics, 17, 38-62. http://dx.doi.org/10.1093/applin/17.1.38

Skehan, P. (1998). Task-based instruction. Annual Review of Applied Linguistics, 18, 268-286.

Skehan, P. (2002). Second language acquisition research and task-based instruction. In Willis, J., \& D. Willis (eds.), Challenge and Change in Language Teaching. Shanghai: Shanghai Foreign Language Education Press. pp. 17-30.

Vygotsky, L. S. (1962). Thought and Language. Cambridge, Mass: MIT Press. http://dx.doi.org/10.1037/11193-000

Vygotsky, L. S. (1978). Mind in Society: The Development in Higher Psychological Progress. Cambridge, Mass: Harvard University Press.

Walshe, R. D. (1987). The learning power of writing. English Journal, 76(6), 22-77.

Wen, Q. F. (2001). Applied Linguistics: Research Methods and Thesis Writing. Beijing: Foreign Language Teaching and Research Press.

Willis, J. (1996). A Framework for Task-based Learning. London: Longman. 
Willis, J. (2002). A flexible framework for task-based learning: Challenge and Change in Language Teaching. Shanghai: Shanghai Foreign Language Education Press. pp. 52-62.

Wolff, D. (2000). Second language writing: a few remarks on psycholinguistic and instructional issues. Learning and Instruction, 10, 107-112. http://dx.doi.org/10.1016/S0959-4752(99)00021-3

Yang, Y. L. (1995). Trends in the teaching of writing. Language Learning Journal, 12, 71-74. http://dx.doi.org/10.1080/09571739585200491

Zhu, M., \& Liu, H.Q. ( 2002). Application of task-based learning in teaching of English writing. Journal of Hebei Angricultural University, 4, 25-30. 